\title{
Effect of Hypoxia on Information Integration Capacities*
}

\section{Efecto de la hipoxia en las capacidades de integración de la} información

Received: 03 September 2017 | Accepted: 15 December 2017

\author{
ERIC FrucharT ${ }^{\mathrm{a}}$ \\ University of Perpignan, Francia \\ ORCID: http://orcid.org/0000-0002-4527-6110 \\ Antoine Raberin \\ University of Perpignan, Francia \\ ORCID: http://orcid.org/0000-0001-5032-8301 \\ Fabienne Durand \\ University of Perpignan, Francia \\ ORCID: http://orcid.org/0000-0002-6157-4855
}

\begin{tabular}{ll}
\hline a Correspondence & author.
\end{tabular}

How to cite: Fruchart, E., Raberin, A., \& Durand, F. (2018). Effect of Hypoxia on Information Integration Capacities. Universitas Psychologica, 17(4), 1-8. http s://doi.org/10.11144/Javeriana.upsy17-4.ehii

\begin{abstract}
The effect of hypoxia on cognitive processes is an undisputed finding but its extent remains difficult to predict in each particular circumstance. The present study examined the impact of hypoxia on information integration capacities in daily life settings. A sample of 14 students was presented with a series of cards depicting an object a) having a given volume and made of a given substance, and asked to infer its mass;or b) having a given mass and density, and asked to infer its volume; or c) having a given volume and mass, and asked to infer its density. There were three levels of hypoxia situations. In a baseline situation, participants were instructed to put a mask connected with an AltiTrainer (equipment that regulates the oxygen partial pressure provided through the mask) and to perform the three judgment tasks in close succession. The two other situations were similar to the baseline situation except that the AltiTrainer was configured to simulate altitude levels either $1100 \mathrm{~m}$ or $3100 \mathrm{~m}$ higher than the one in the baseline situation. Contrary to our expectations, no difference in performance was found between the three experimental situations. People's information integration capacities are not affected by hypoxia, even if acclimatization to it has not taken place, and as far as it is not too severe.
\end{abstract}

Keywords

hypoxia; AltiTrainer; information integration.

\section{RESUMEN}

El efecto de la hipoxia en los procesos cognitivos es un hallazgo indisputado, pero su alcance continúa siendo difícil de predecir en cada circunstancia particular. El presente estudio examinó el impacto de la hipoxia en las capacidades de integración de la información en el contexto de la vida diaria. A una muestra de 14 estudiantes se le presentaron una serie de cartas representando un objeto a) teniendo un volumen dado y creado de una sustancia dada, y se le pidió que infiriera su masa, o b) teniendo una masa y densidad dadas, y se le pidió que infiriera su volumen, o c) teniendo un volumen y masa dados, y se le pidió que infiriera su densidad. Existieron tres niveles de situaciones de hipoxia. 
En una situación de línea base, a los participantes se les pidió que se pusieran una máscara conectada con un AltiTrainer (equipo que regula la presión parcial de oxigeno que se provee a través de la máscara), y que realizaran las tres tareas de juicio sucesivamente. Las otras dos situaciones fueron similares a la situación de línea base, excepto que el AltiTrainer fue configurado para simular niveles de altitud de 1100 m o 3100 m más altos que los de la situación de línea base. Contrario a nuestras expectativas, no se encontraron diferencias en el desempeño entre las tres situaciones experimentales. Las capacidades de integración de la información de las personas no fueron afectadas por la hipoxia, incluso si la aclimatación a ella no tuvo lugar, y esta no fue muy severa.

Palabras clave

hipoxia; AltiTrainer; integración de la información.

With increasing altitude, the total atmospheric pressure exponentially decreases, resulting in a partial pressure of oxygen $\left(\mathrm{PaO}_{2}\right)$ reduction in arterial blood and in tissues called hypoxia (Rupp et al., 2013). In two recent reviews of findings, Taylor, Watkins, Marshall, Dascombe and Foster (2016), and McMorris, Hale, Barwood, Costello and Corbett (2017) suggested that hypoxia impacts not only on cognitive abilities in complex tasks involving working memory and central executive processes but also on simple tasks involving perception/attention and short-term memory. Legg et al. (2014) showed that mild hypoxia impacted on complex logical reasoning but did not impact on self-perceived risk judgment.

Although the effect of hypoxia on cognitive processes is undisputed, it remains difficult to predict its extent in particular circumstances (Davranche et al., 2016): Clear impairment of cognitive functions has been found in some tasks (e.g., Dykiert et al., 2010) whereas no impairment has been detected in apparently similar tasks (e.g., Latshang et al., 2013). Heterogeneousness of tasks, duration and severity of hypoxia, acclimatization versus nonacclimatization to hypoxia, experimental context (laboratory study vs. field study), and individual response variability (Davranche et al., 2016; Petrassi, Hodkinson, Walters, \& Gaydos, 2012) have been evoked to explain these discrepancies.

\section{The present study}

The present study was aimed at complementing the previous studies by examining the impact of hypoxia on information integration capacities in daily life settings. The chosen judgment situation was borrowed from elementary physics and concerned the relationships between mass, volume and density. It was chosen because these three concepts are some of the most commonly used ones in everyday life. Although they are taught in school in a systematic way, people, as a general rule, construct a representation of these notions much before the classroom exposure to them, and develop these notions during their whole lifetimes. Intuitive notions of mass or density are crucial to everyday actions such as taking, lifting, moving, and carrying. Over the course of development, children, adolescents, and adults, necessarily perform these types of actions countless numbers of times. This enables them to build up a representation of the functional relationships between mass and volume and/or mass and substance (density) and/ or volume and substance. Another reason why this situation was selected is that the many findings as regards the perceived relationships between these concepts, obtained in previous studies among children, adolescents, and young and older adults (Chartier, Mullet, \& Grandjean, 1991; Léoni \& Mullet, 1993; Léoni, Mullet, \& Chasseigne, 2002; Mullet \& Gervais, 1990) offered a background for the present study.

In physics, the relationship between mass, volume and density can be expressed by the following equation: Mass $=$ Volume $\mathrm{x}$ Density. The right hand panel in Figure 1 graphically expresses the multiplicative character of the relationship expressed in this equation. On the horizontal axis are three density levels. On the vertical axis are theoretical mass values. The three curves correspond to three possible volumes. All three curves are ascending: The higher the density of an object, the higher the mass. Curves are clearly separated: The larger the volume, the higher the mass. In addition, the three curves form a linear fan open to the right with the large volume curve on the top and 
the small volume curve on the bottom. Previous studies (e.g., Léoni et al., 2002) have shown that a majority of young adults are able to integrate volume and density information in a correct, multiplicative way.

The Volume $=$ Mass / Density equation is obtained by simple derivation from the preceding equation. For a physicist, these two equations are equivalent. Switching from one to the other is simply a matter of fairly trivial rewriting. From an information integration perspective, however, these two equations are far from being equivalent. Intuitive mastery of the Volume equation presupposes: a) as for the Mass equation, recognition of the direct relationship between mass and volume, and b) recognition of an inverse relationship between density and volume (the greater the density, the lower the volume, at constant mass). The center panel in Figure 1 graphically expresses the divisive character of the relationship expressed in the Volume equation. All three curves were descending: The higher the density of an object, the lower the volume. Curves were clearly separated: The higher the mass, the larger the volume. In addition, the three curves formed a linear fan open to the left with the high mass curve on the top and the small mass curve on the bottom. Previous studies (e.g., Léoni et al., 2002) have shown that only a minority (20\%) of young adults are able to integrate mass and density information in a correct, divisive way. A majority of them integrate both pieces of information in a subtractive way (mass minus density). In other words, the volume condition represents, from a judgmental viewpoint, a much more difficult situation than the mass condition.

\section{Figure 1}

Theoretical patterns illustrating the physically correct relationship between mass, volume and density
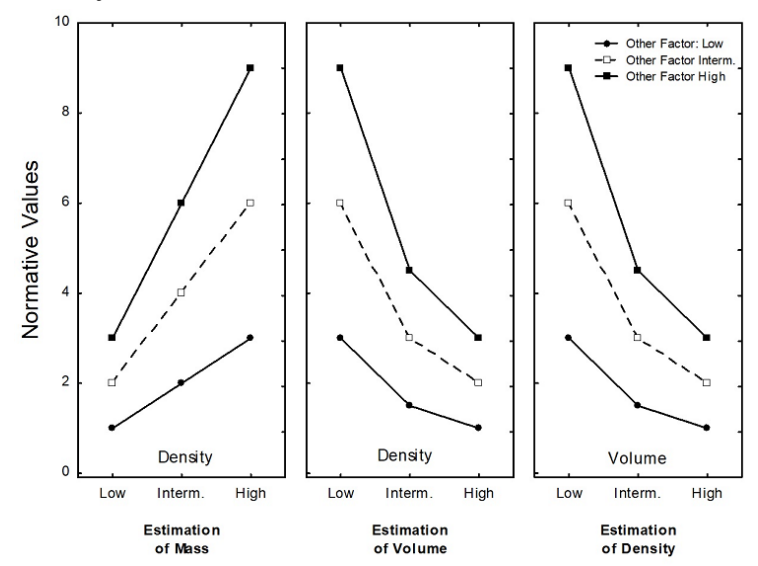

The Density $=$ Mass / Volume equation can in the same way be obtained by derivation from the Mass equation. The same comments made for the Volume equation apply to the Density equation. The right hand panel in Figure 1 graphically expresses the divisive character of the relationship expressed in this equation. Previous studies (e.g., Léoni et al., 2002) have shown that only a minority $(21 \%)$ of young adults are able to integrate mass and volume information in a correct, divisive way. As in the preceding case, a majority of them integrate both pieces of information in a subtractive way (mass minus volume).

\section{Hypothesis}

Our main hypothesis was that hypoxia would impact on information integration capacities in a different way according to the difficulty of the judgment task. In the mass estimation situation, the effect of hypoxia would be minimal. Estimating the mass of a body from its perceived volume and from what is known about its substance (density) to prepare for the act of lifting (muscle tone) takes a few seconds and is commonplace. In other words, daily reality offers numerous opportunities for the learning of the relationship depicted in the Mass equation. 
Hypoxia is unlikely to have a major impact on information integration in an overlearned judgment task: A majority of participants in all three groups would integrate information in a multiplicative way and a minority of participants would integrate information in an additive way (see Léoni et al., 2002, Figure 2).

In both other situations, the effect of hypoxia would be stronger. Inferring the volume of a body from information on mass and density is a more specific activity, which can take place in physics classes but probably never occurs in everyday life situations. One of the reasons why volume is never judgmentally assessed is that we have direct (visual) access to information on volume, but not for mass (except where there is direct kinesthetic information). As a result, the Volume equation can be seen as a formal expression for only a limited set of school activities. As regards now the inference of density, it is easier to imagine everyday situations that can be formalized by the Density equation. There are instances where we assay an object in our hands to get an idea of the material it is made of (density), for example, when there are reasons to believe that the material of which an object seems to be made is actually different from the material of which it is really made. Information on density is, however, most of the time, directly accessible from visual inspection.

In summary, while the latter task can somewhat be based on everyday life experience, the former task is entirely based on abstract/ logical reasoning. As a result, hypoxia is likely to have a major impact on information integration in both tasks, and more so in the inference of volume task than in the inference of density task. A majority of participants in the baseline condition would integrate information either in a divisive (correct) way or in a subtractive (suboptimal) way (see Léoni et al., 2002, Figures 3 and 4) whereas only a minority of the participants would be able to do so in hypoxia conditions: These participants would be unable to integrate information and would take into account only one piece of information for judging (see Léoni et al., 2002, Figure 4, right hand panels).

\section{Method}

\section{Participants and Material}

Participants were 14 students (50\% males) aged 20-24 preparing for a Master in sport science. They lived in a Pyrenean sport center in the Font Romeu area.

The material used in the Mass condition was composed of 11 cards $(50 \mathrm{~cm} \times 30 \mathrm{~cm})$. A drawing of a balance beam appeared on each card. The left-hand pan of the balance was shown having an object with a given volume and made of a given substance. Nine of the cards corresponded to a $3 \times 3$, Volume (low, intermediate, and high) x Density (iron, wood, and plastic) orthogonal factorial design. The two remaining cards depicted (a) an extremely low volume object made of plastic, and (b) a very large volume object made of iron.

The material used in the Volume condition (11 cards) presented a drawing of a balance scale where the left-hand pan had a certain number of "weights". The right-hand pan was shown having an object made of a given substance but whose volume was unknown. Nine of the cards corresponded to a $3 \times 3$, Density (iron, wood, and plastic) $\mathrm{x}$ Mass (two, three, or four weights) orthogonal factorial design. The two remaining cards represented a single weight offset by an object made of iron, and the other depicted five weights offset by an object made of plastic.

The material used in the Density condition (11 cards) presented a drawing of a balance scale where the right-hand pan had an object with defined volume, made of an unspecified material. The left-hand pan had a variable number of weights. Nine of the cards corresponded to a $3 \mathrm{x}$ 3 , Mass $x$ Volume orthogonal factorial design (see above). One of the remaining cards depicted an object with a very large volume, which is offset by a single weight; the other card depicted an object with low volume, offset by five weights. 
Procedure

The baseline situation was $1300 \mathrm{~m}$. There were three experimental sessions of about 20-30 minutes that were separated by at least one week. The order of these sessions was counterbalanced across participants. In each session participants were asked to put a mask connected to an AltiTrainer. This equipment regulated the oxygen partial pressure provided to the participant by diluting azote and oxygen in air. Arterial oxygen saturation $\left(\mathrm{SaO}_{2}\right)$ associated to hypoxia was measured with a finger pulse oximeter to check whether the severity of hypoxia was the one that was expected.

During Session 1, participants, after having put the mask and the finger pulse oximeter, were administered each condition in succession. Instructions were given verbally. In the mass condition they were asked to estimate the mass of each object using a 21-point response scale ranging from Light to Heavy. In the volume and density conditions the corresponding response scales ranged from Small to Large and from Low and High. The interval between conditions was of ten minutes. Order of presentation was, as far as possible, counterbalanced: a) five participants were placed in the mass condition first, and then either in the density or in the volume condition; b) five participants were placed in the volume condition first, and then either in the density or in the mass condition; and c) four participants were placed in the density condition first, and then either in the volume or in the mass condition. Testing was individual and took place in two phases - familiarization and experimental - as described in Léoni et al. (2002. See also Anderson, 1996, 2016).

Sessions 2 and 3 were similar to Session 1 except that the AltiTrainer was configured to administer the level of oxygen usually found at an altitude of either $2400 \mathrm{~m}$ or $4400 \mathrm{~m}$; that is, either $1100 \mathrm{~m}$ (Session 2) or $3100 \mathrm{~m}$ (Session 3) higher than the baseline.

\section{Results}

The patterns of estimations observed in the Mass condition and for each altitude level are shown in the top raw of Figure 2. In each of the three panels, the pattern was reminiscent of the theoretical one shown in Figure 1. An ANOVA with an Altitude $\mathrm{x}$ Volume $\mathrm{x}$ Density, 3 x 3 x 3 design was conducted on the raw data. As shown in Table 2, the Volume x Density interaction was significant and concentrated in its bilinear component but no interaction involving the altitude factor was significant. Each individual data pattern was subsequently analyzed. Out of the 42 patterns $(14 \times 3), 34$ (81\%) were clearly diverging on the right: 10 in the baseline situation, 13 in the $2400 \mathrm{~m}$ situation, and 11 in the $4400 \mathrm{~m}$ situation.

The patterns of estimations observed in the Volume condition are shown in the second raw of Figure 2. In each of the three panels, the pattern was different from the theoretical one shown in Figure 1. It was a pattern of parallelism. The Mass x Density interaction was not significant. The Altitude $\mathrm{x}$ Mass interaction was significant, and concentrated in its bilinear component. In the baseline situation, the effect of mass was stronger than in the $4400 \mathrm{~m}$ situation. In the baseline situation, the difference between mean judgments when the mass was high and mean judgments when it was low was $15.07-3.67$ $=12.6$. In the $4400 \mathrm{~m}$ situation, it was 14.4 $3.93=10.47$. No other interaction involving the altitude factor was significant. Visual inspection of individual patterns showed that only 16 (38\%) were, as in Figure 1, clearly diverging on the left: five in the baseline situation, six in the $2400 \mathrm{~m}$ situation, and five in the $4400 \mathrm{~m}$ situation.

The patterns of estimations observed in the Density condition are shown in the bottom raw of Figure 2. As in the volume condition, the pattern was a pattern of parallelism. The Mass $\mathrm{x}$ Volume interaction was significant but its bilinear component was not. No other interaction involving the altitude factor was significant. Inspection of individual patterns showed that only three (7\%) were, as in Figure 
1, clearly diverging on the left: one in each situation.

\section{Discussion}

This study was the first one to examine the effect of hypoxia on information integration capacities. Contrary to our expectations, no difference in performance was found between the three experimental sessions. In the Mass condition, the mean pattern of judgments was similar to the one reported in Léoni et al. (2002), and the percentage of participants who integrated the volume and density information in a correct, multiplicative way was higher (81\%) than the one found among 20-35-year-old participants $(61 \%)$ in this study, which can be attributed to the fact that all participants were university students. In the Volume condition, the percentage of participants who integrated the mass and density information in a correct, divisive way was also higher (38\%) than the one (20\%) found in Léoni et al. (2002)'s study. Finally, in the density condition, the percentage of participants who integrated the mass and volume information in a correct way was somewhat lower (7\%) than the one $(21 \%)$ found in Léoni et al. (2002)'s study.
Figure 2

Patterns of results showing the perceived relationship between mass, volume and density in the three conditions and the three levels of altitude
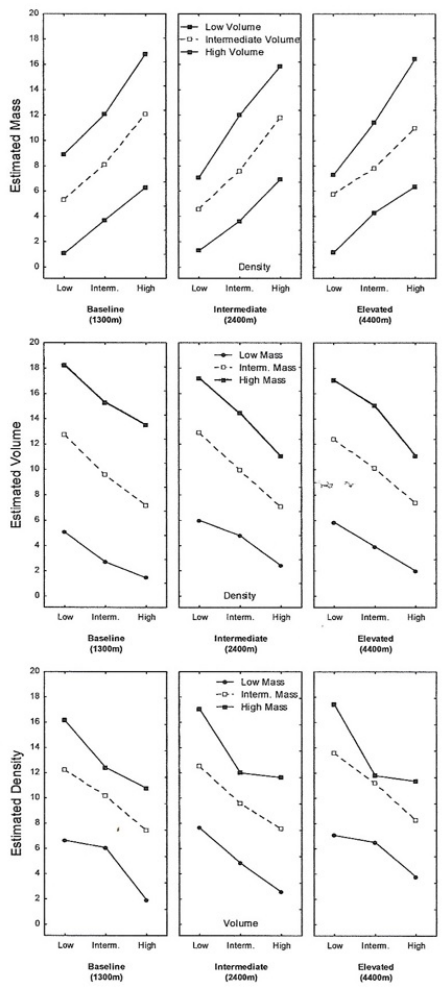

The lack of any clear effect of hypoxia on information integration capacities cannot be attributed to the level of difficulty of the tasks. Inferring the mass of an object from volume and density information is, as already stated above, a judgment task that is quite easy: Ninthgrade students have been shown to be able to perform it in a correct way (Léoni \& Mullet, 1993). However, inferring the volume of an object from mass and density information or inferring the density of an object from mass and volume information are judgment task that are much more difficult. Both judgments tasks were demanding, and previous studies have shown that a variable that is classically associated with information processing capacities such as age directly impacts on performance. An effect of hypoxia on information integration, if such an effect existed, should have manifested itself through the emergence of non-integration 
patterns as was found in Léoni et al.'s (2002) older participants.

As already stated, the difference of findings in literature on the effect of hypoxia on high cognitive process has been mainly explained by divergences in the methods used (Davranche et al., 2016). In many situations, however, no significant effects on cognitive performance have, as in the present study, been detected (Hewett, Curry, Rath, \& Collins, 2009; Komiyama et al., 2015; Latshang et al., 2013; Legg et al., 2014; Pavlicek et al., 2005; Tripathi, Apte, \& Mukundan, 2005). It can, therefore, be safely concluded that people's information integration capacities are not affected by hypoxia, even if acclimatization to it has not taken place, and as far as it is not too severe; that is, corresponding to an altitude that is lower than $4500 \mathrm{~m}$.

\section{Limitations}

The main limitation of the study resides in that the sample was not a standard sample. It was composed of students in sport science living in altitude. This is a common limitation to most studies of this kind. It remains, however, to be shown whether the current findings apply to samples of ordinary people living at lower altitudes.

\section{References}

Anderson, N. H. (1996). A functional theory of cognition. Mahwah, NJ: Erlbaum.

Anderson, N. H. (2016). Information Integration Theory: Unified Psychology based on three mathematical laws. Universitas Psychologica, 15(3). https://doi.org/10.11144/Javeriana.u psy15-3.iitu

Chartier, D., Mullet, E., \& Grandjean, J. C. (1991). Effectiveness of a physics computer program on 15-year old "technology" students. Journal of Educational Computing Research, 7(2), 219-232. https://doi.org/10. 2190/QQD5-CFVY-5VGF-5YBM
Davranche, K., Casini, L., Arnal, P. J., Rupp, T., Perrey, S., \& Verges, S. (2016). Cognitive functions and cerebral oxygenation changes during acute and prolonged hypoxic exposure. Physiology $\mathbb{E}$ Behavior, 164(Part A), 189-197. https://doi .org/10.1016/j.physbeh.2016.06.001

Dykiert, D., Hall, D., Van Gemeren, N., Benson, R., Der, G., Starr, J. M., \& Deary, I. J. (2010). The effects of high altitude on choice reaction time mean and intra-individual variability: Results of the Edinburgh Altitude Research Expedition of 2008. Neuropsychology, 24(3), 391-401. htt ps://doi.org/10.1037/a0018502

Hewett, K. J., Curry, I. P., Rath, E., \& Collins, S. M. (2009). Subtle cognitive effects of moderate hypoxia. Fort Rucker, AL: USAARL.

Komiyama, T., Sudo, M., Higaki, Y., Kiyonaga, A., Tanaka, H., \& Ando, S. (2015). Does moderate hypoxia alter working memory and executive function during prolonged exercise? Physiology $\&$ Behavior, 139, 290-296. https://doi.org/10.1016/j.phy sbeh.2014.11.057

Latshang, T. D., Lo Cascio, C. M., Stöwhas, A. C., Grimm, M., Stadelmann, K., Tesler, N., ... Bloch, K. E. (2013). Are nocturnal breathing, sleep, and cognitive performance impaired at moderate altitude (1,630-2,590 m)? Sleep, 36(12), 1969-1976. https://doi.o $\mathrm{rg} / 10.5665 /$ sleep.3242

Legg, S., Hill, S., Gilbey, A., Raman, A., Schlader, Z., \& Mundel, T. (2014). The effect of mild hypoxia on working memory, complex logical reasoning, and risk judgment. The International Journal of Aviation Psychology, 24(2), 126-140. https://doi.org/10.1080/10 508414.2014.892751

Léoni, V., \& Mullet, E. (1993). Evolution of the intuitive mastery of the relationships between mass, volume, and density from nursery school to college. Genetic, Social, and General Psychology Monographs, 119(3), 389-412.

Léoni, V., Mullet, E., \& Chasseigne, G. (2002). Aging and intuitive physics. Acta 
Psychologica, 111(1), 29-43. https://doi.org/ 10.1016/S0001-6918(01)00077-4

McMorris, T., Hale, B. J., Barwood, M., Costello, J., \& Corbett, J. (2017). Effect of acute hypoxia on cognition: A systematic review and meta-regression analysis. Neuroscience and Biobehavioral Reviews, 74(Part A), 225-232. https://doi.org/10.1016/j.neubiore v.2017.01.019

Mullet, E., \& Gervais, H. (1990). Distinction between the concepts of weight and mass in high school students. International Journal of Science Education, 12(2), 217-226. https://d oi.org/10.1080/0950069900120210

Pavlicek, V., Schirlo, C., Nebel, A., Regard, M., Koller, E. A., \& Brugger, P. (2005). Cognitive and emotional processing at high altitude. Aviation, Space, and Environmental Medicine, 76(1), 28-33.

Petrassi, F. A., Hodkinson, P. D., Walters, P. L., \& Gaydos, S. J. (2012). Hypoxic hypoxia at moderate altitudes: review of the state of the science. Aviation, Space, and Environmental Medicine, 83(10), 975-984. h ttps://doi.org/10.3357/ASEM.3315.2012

Rupp, T., Leti, T., Jubeau, M., Millet, G. Y., Bricout, V. A., Levy, P., ... Verges, S. (2013). Tissue deoxygenation kinetics induced by prolonged hypoxic exposure in healthy humans at rest. Journal of Biomedical Optic, 18(9), 095002. https://doi.org/10.1117/1.JB O.18.9.095002

Taylor, L., Watkins, S. M., Marshall, H., Dascombe, B. J., \& Foster, J. (2016). The impact of different environmental conditions on cognitive function: A focused review. Frontiers in Physiology, 6, 1-12. https://doi.org/10.3389/fphys.2015.0 0372

Tripathi, K., Apte, C., \& Mukundan, C. (2005). Temporal adjustments in working memory and vigilance function during 6 days of acclimatization at 10,500 feet altitude. Indian Journal of Aerospace Medicine, 49(1), 20-28.

\section{Appendix}

\section{Results of the ANOVAS in each of the Three Conditions}

\begin{tabular}{|c|c|c|c|c|c|}
\hline \multirow{2}{*}{\multicolumn{6}{|c|}{ Estimation of Mass }} \\
\hline & & & & & \\
\hline Altitude (A) & 2 & 6.04 & 0.8 & 0.46 & 0.06 \\
\hline Volume (V) & 2 & 2088.1 & 233.24 & 0.001 & 0.95 \\
\hline Density (D) & 2 & 1460.03 & 91.5 & 0.001 & 0.88 \\
\hline $\mathrm{A} \times \mathrm{V}$ & 4 & 5.11 & 1.69 & 0.17 & 0.11 \\
\hline$A \times D$ & 4 & 1.72 & 0.57 & 0.68 & 0.04 \\
\hline V x D & 4 & 30.32 & 7.05 & 0.001 & 0.35 \\
\hline Bilinear & 1 & 111.72 & 18.37 & 0.001 & \\
\hline$A \times V \times D$ & 8 & 3.45 & 1.32 & 0.24 & 0.09 \\
\hline \multicolumn{6}{|c|}{ Estimation of Volume } \\
\hline Altitude (A) & 2 & 0.46 & 0.06 & 0.94 & 0 \\
\hline Mass (M) & 2 & 3806.46 & 118.7 & 0.001 & 0.9 \\
\hline Density (D) & 2 & 770.21 & 45.72 & 0.001 & 0.78 \\
\hline $\mathrm{A} \times \mathrm{M}$ & 4 & 22.3 & 3.51 & 0.01 & 0.21 \\
\hline Bilinear & 1 & 47.15 & 6.3 & 0.03 & \\
\hline$A \times D$ & 4 & 3.98 & 0.69 & 0.6 & 0.05 \\
\hline$M \times D$ & 4 & 12.81 & 1.65 & 0.18 & 0.11 \\
\hline Bilinear & 1 & 39.05 & 3.55 & 0.08 & \\
\hline $\mathrm{A} \times \mathrm{M} \times \mathrm{D}$ & 8 & 1.77 & 0.46 & 0.88 & 0.03 \\
\hline \multicolumn{6}{|c|}{ Estimation of Density } \\
\hline Altitude (A) & 2 & 27.25 & 2.19 & 0.13 & 0.14 \\
\hline Mass (M) & 2 & 2092.15 & 118.31 & 0.001 & 0.9 \\
\hline Volume (V) & 2 & 797.02 & 52.03 & 0.001 & 0.8 \\
\hline $\mathrm{A} \times \mathrm{M}$ & 4 & 4 & 0.49 & 0.74 & 0.04 \\
\hline $\mathrm{A} \times \mathrm{V}$ & 4 & 4.2 & 0.5 & 0.74 & 0.04 \\
\hline$M \times V$ & 4 & 42.83 & 4.86 & 0.001 & 0.27 \\
\hline Bilinear & 1 & 16.72 & 1.28 & 0.28 & \\
\hline $\mathrm{A} \times \mathrm{M} \times \mathrm{V}$ & 8 & 3.03 & 0.59 & 0.79 & 0.04 \\
\hline
\end{tabular}

\section{Notes}

* Research article. 